\title{
Effect of Genistein on ATP-induced Cell Retraction and Rounding in Human Chang Liver Cells
}

\author{
By \\ B.H. BAY \\ Department of Anatomy, National University of Singapore, Kent Ridge, Singapore 119260 \\ -Received for Publication, April 16, 1997 - \\ Key Words: Extracellular ATP, Tyrosine kinase specific inhibitor, Scanning electron microscopy, Confocal microscopy \\ Summary: Extracellular ATP has been previously reported to induce cell retraction and stimulate DNA synthesis in \\ human Chang liver cells via phosphoinositide (PI) signal transduction. The ATP-treated cell assumes a rounded mor- \\ phology and is tethered to the substratum by microvillous anchors as demonstrated in this study by scanning electron \\ and confocal microscopy. The addition of $0.5 \mathrm{mM}$ genistein, which is known to completely abolish extracellular ATP- \\ stimulated DNA synthesis in Chang liver cells, did not inhibit ATP-induced cell rounding. The results suggest that the \\ seemingly conjoint responses of ATP-stimulated DNA synthesis and cell rounding could be dissociated.
}

Genistein, a known tyrosine kinase inhibitor (Akiyama et al., 1987) has been reported to inhibit DNA synthesis in phosphotyrosine kinase (PTK) dependent and non-PTK dependent pathways (Gaudette and Holub, 1990; Sit et al., 1992a). Because of its antiproliferative activity, this isoflavone has been cited as a potential anti-cancer agent in the chemoprevention and chemotherapy of human breast and prostate cancers (Barnes et al., 1995) and experimental breast cancer (Lamartinere et al., 1995).

Genistein at $0.5 \mathrm{mM}$ concentration has been shown to completely abolish ATP-stimulated DNA synthesis but not intracellular alkalinization in Chang liver cells (Sit et al., 1991). It is well established that extracellular ATP binds P2-purinergic receptors (Burnstock, 1990) and activates phosphoinositide-specific phospholipase C (PLC) (Dubyak et al., 1988) which in turn generates the PI second messengers, diacylglycerol (DAG) and inositol $1,4,5$ trisphosphate $\left(\mathrm{IP}_{3}\right)$. DAG is known to stimulate $\mathrm{Ca}^{2+} /$ phospholipid dependent protein kinase C (PKC) which causes allosteric activation of the $\mathrm{Na}^{+} / \mathrm{H}^{+}$antiporter (Ober and Pardee, 1987; Nishizuka, 1989; Bay and Sit, 1993; Bay et al., 1996a).

Since upshifting of intracellular $\mathrm{pH}\left(\mathrm{pH}_{\mathrm{i}}\right)$ induced by extracellular ATP has been associated with cell retraction and rounding (a process which is important in the metastatic cascade) (Sit et al., 1992b; Bay et al., 1996b), the effect of genistein on ATP-induced cell rounding was evaluated.

\section{Materials and Methods}

\section{Cell cultures}

Human Chang liver cells (American Type Culture Collection, ATCC CCL 13) were cultured in Dulbecco's modified Eagles medium (DMEM, Sigma, USA) supplemented with $10 \%$ foetal bovine serum (Cytosystems, Australia) and $10 \% \mathrm{CO}_{2}$ in air. Cells were seeded at $3 \times 10^{5}$ cells per $25 \mathrm{~cm}^{2}$ culture flask (Costar, USA) by the Filamatic dispenser (National Instrument, USA).

ATP induced cell rounding with and without genistein

Parallel $25 \mathrm{~cm}^{2}$ cultures were rinsed with $2 \times 10$ $\mathrm{ml} \mathrm{Na}{ }^{+}$-HEPES buffer [140 mM NaCl, $10 \mathrm{mM}$ HEPES (Sigma) adjusted to pH 7.4 with $\mathrm{NaOH}$ ] and overlaid with $2 \mathrm{ml} \mathrm{Na}{ }^{+}$-HEPES buffer containing $7 \mathrm{mM}$ ATP (adenosine 5'-triphosphate, sodium salt, Sigma) with and without $0.5 \mathrm{mM}$ genistein (Funakoshi Pharmaceutical, Japan). Cultures were incubated at $37^{\circ} \mathrm{C}$ for the required duration in time response. Cells were fixed after $0,4,8,15 \mathrm{~min}$ in NAMETCA $(140 \mathrm{mM} \mathrm{NaCl}$ in $70 \%$ methanol acidified with $3 \%$ trichloroacetic acid) and stained with Giemsa's stain [Gurr's improved R66 (BDH, UK)]. Slides were examined in a Nikon microscope 
on line with the Quantimet image analysis system. Cell profile area, perimeter and cell rounding were measured using the QUIPS programme (Bay et al., 1996b).

\section{Scanning electron microscopy}

Cells were fixed in $5 \%$ glutaraldehyde in $0.1 \mathrm{M}$ phosphate buffer ( $\mathrm{pH} \mathrm{7.2)} \mathrm{for} 30$ minutes. This was followed by osmication with $2 \%$ osmium tetroxide as previously described (Bay et al., 1997). After dehydration, cells were dried in the Balzers Critical Point Dryer model CPD030, using liquefied carbon dioxide. Samples were coated with $20 \mathrm{~nm}$ of gold in a Balzers Sputter Coater before examination in a Philips SEM 515 scanning electron microscope.

\section{Confocal microscopy}

Imaging was done in the BioRad MRC600 confocal system equipped with a $25 \mathrm{~mW}$ argon laser. Cells were visualized in a Bio-Rad M17 upright microscope. The light output was reduced to $3 \%$ of total power by a neutral density filter.

\section{Results and Discussion}

Added ATP caused a reduction in the cell profile area and perimeter in the time response (Fig. 1). The cell profile area reduced by approximately $75 \%$ from a mean of $1045 \mu \mathrm{m}^{2}$ to $141 \mu \mathrm{m}^{2}$ at the end of 15 minutes (Fig. 1A). The cell profile perimeter diminished by approximately $70 \%$ from a mean of $320 \mu \mathrm{m}$ to $47 \mu \mathrm{m}$ at the end of 15 minutes (Fig. 1B). The addition of $0.5 \mathrm{mM}$ genistein to the ATP incubation buffer had no significant effect on the reduction in profile area and perimeter $(p<0.05$, ANOVA).

Concurrent with the reduction in profile area and perimeter, ATP-treated Chang liver cells undergo a flat to round change in morphology as evidenced by the increasingly rounded cell profile (Fig. 2). No significant difference was observed in the cell rounding response of ATP-treated cells in the presence or absence of genistein. At the end of 15 minutes, ATP-treated cells were retracted from the substratum and characterized by multiple long thin processes which maintained contact with the substratum (Fig. 3). The progression of untreated human Chang liver cells from a flattened anchored state into a rounded morphology with ATP incubation is shown in Fig. 4. Cells round up as a result of a drastic reduction of cell surface area due to massive internalization of plasma membrane by antiport mediated endocytosis (Sit et al., 1994; Bay et al., 1996b).

ATP is also known to stimulate DNA synthesis via activation of $\mathrm{PKC}$, a serine-threonine kinase (Nishizuka, 1992; Azzi et al., 1992). It appears that genistein is able to completely suppress ATPstimulated DNA synthesis (Sit et al., 1991) by its inhibitory action on tyrosine kinase (Akiyama et al., 1987). Genistein has been shown to directly reduce the phosphorylation of oncogenic proteins and other substrates (Nishimura, 1995).

However, genistein did not inhibit ATP-induced cell retraction and rounding. Release of cells from anchorage to the substratum must occur before cells can disseminate to distant foci (Juliano, 1987). The observation that the seemingly conjoint responses of ATP-induced cell rounding and stimulated DNA synthesis are separable, suggest that DNA damage or suppression in cancers by chemotherapeutic agents (Berger \& Hirschler, 1992) may not necessarily affect their metastatic potentials.

\section{Acknowledgments}

The author is grateful to Mr. P. Gobalakrishnan and Ms Y.G. Chan for technical assistance and Mrs. Alice Bay for secretarial assistance. The use of the laboratory facilities of Prof. K.H. Sit is acknowledged.

\section{References}

1) Akiyama $R$, Ishida J, Nakagawa $S$, Ogawara $H$, Watanabe S, Itoh N, Shibuya $M$ and Fukami Y. Genistein, a specific inhibitor of protein kinase. J Biol Chem 1987; 262:55925595.

2) Azzi A, Boscoboinik D and Hemsey C. The protein kinase C family. Eur J Biochem 1992; 208:547-557.

3) Barnes S, Peterson TG and Coward L. Rationale for the use of genistein-containing soy matrices in chemoprevention trials for breast and prostate cancer. J Cell Biochem Suppl 1995; 22:181-187.

4) Bay BH and Sit KH. Cell shape changes mediated by sulphate in the Cloudman mouse melanoma cell line. J Comp Pathol 1993; 108:209-213.

5) Bay BH, Sit KH and Liau LS. Cytosolic calcium mobilization concomitant with cell retraction induced by sulphate in oral KB carcinoma cells. Anticancer Research 1996a; 16:821-826.

6) Bay BH, Sit KH, Paramanantham R and Wong KP. ATP induces large channel endocytosis with concomitant increase in cell density. Okajimas Folia Anat Jpn 1996b; 73:334-338.

7) Bay BH, Sit KH, Paramanantham R and Chan YG. Hydroxyl free radicals generated by vanadyl [4] induce cell blebbing in mitotic human Chang liver cells. Bio Metals 1997; 10:119-122.

8) Berger NA and Hirschler N. Therapeutic strategies for cancer chemotherapy based on consequences of DNA damage. Ann NY Acad Sci 1988; 551:415-520.

9) Burnstock G. Overview: purinergic mechanisms. Ann NY Acad Sci 1990; 603:1-17. 
10) Dubyak GR, Gowen DS and Lazarus HM. Activation of the phosphoinositol signalling system by receptors for extracellular ATP in human neutrophils, monocytes, and neutrophil/monocyte progenitor cells. Ann NY Acad Sci 1988; 551:218-238.

11) Gaudette DC and Holub BJ. Effect of genistein, a tyrosine kinase inhibitor, on U65510-induced phosphoinositide phosphorylation in human platelets. Biochem Biophys Res Commun 1990; 170:238-242.

12) Juliano RL. Membrane receptors for extracellular macromolecules, relationship to cell adhesions and tumor metastasis. Biochim Biophys Acta 1987; 907:261-278.

13) Lamatiniere CA, Moore JB, Brown NM, Thompson R, Hardin MJ and Barnes S. Genistein suppresses mammary cancer in rats. Carcinogenesis 1995; 16:2833-2840.

14) Nishimura J, Takahira H, Shibuta K, Muta K, Yamamoto $M$, Ideguchi $H$, Umemura $T$ and Nawata $H$. Regulation of biosynthesis and phosphorylation of $\mathrm{p} 210^{\mathrm{br}} / \mathrm{abl}$ protein during differentiation of K562 cells. Leuk Res 1990; 12:875-885.

15) Nishizuka $Y$. The family of protein kinase $C$ for signal transduction. J Amer Med Assoc 1989; 262:1826-1833.
16) Nishizuka Y. Intracellular signalling by hydrolysis of phospholipids and activation of protein kinase C. Science 1992; 258:607-613.

17) Ober SS and Pardee AB. Both protein kinase $C$ and calcium mediate activation of the $\mathrm{Na}^{+} / \mathrm{H}^{+}$antiporter in Chinese Hamster embryo fibroblasts. J Cell Physiol 1987; 132:311-317.

18) Sit KH, Wong KP and Bay BH. Effects of genistein on ATP induced DNA synthesis and intracellular alkalinization in Chang liver cells. Japan J Pharmacol 1991; 57:109111.

19) Sit $\mathrm{KH}$, Wong $\mathrm{KP}$ and Bay BH. Genistein inhibits DNA synthesis but has no effect on levels of $D A G$ and $\mathrm{IP}_{3}$, cell rounding and alkalinization in sulphate-treated Chang liver cells. Biol Signals 1992a; 1:228-236.

20) Sit KH, Bay BH and Wong KP. Extracellular ATP induces rapid cell rounding in cultured Chang liver cells. Japan J Physiol 1992b; 42:355-362; 1992.

21) Sit KH, Bay BH and Wong KP. Internalization of large macromolecules in human Chang liver cells by extracellular ATP. Okajimas Folia Anat Jpn 1994; 70:247-254. 
Plate I
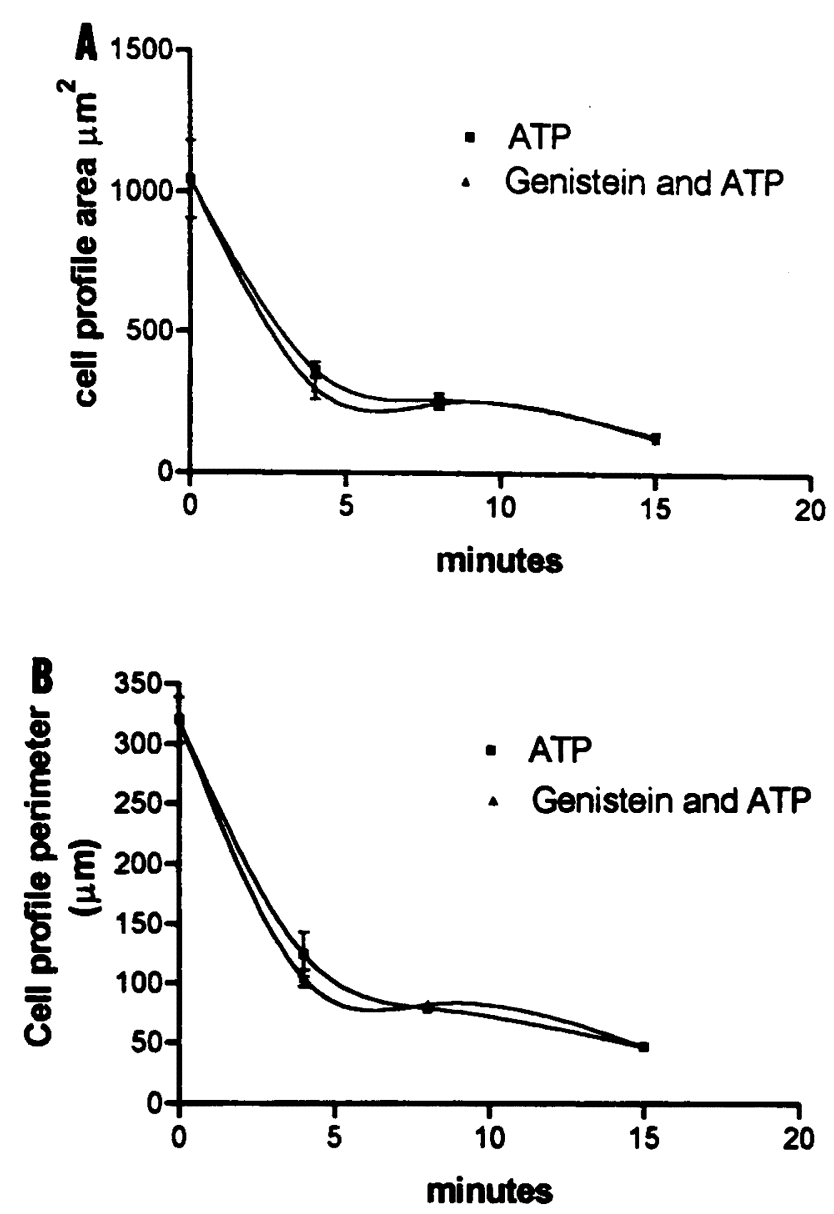

Explanation of Figures

Plate I

Fig. 1. Profile area and perimeter of human Chang liver cells in $7 \mathrm{mM}$ ATP-treated cells with and without $0.5 \mathrm{mM}$ genistein: time response. (A) Cell profile area. (B) Cell profile perimeter. Error bar $=2 \mathrm{SE}$.

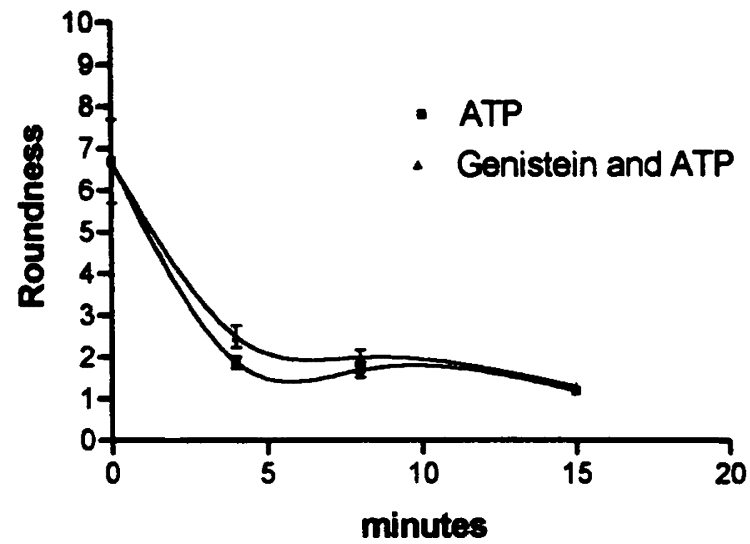

Fig. 2. Roundness form factor according to the formula (perimeter) ${ }^{2} / 4 \pi$ (area). Roundness form factor in untreated Chang liver cells was 6.7 and in ATP treated cells were 1.2 (without genistein) and 1.3 (with genistein). When the value is 1 , the cell is perfectly round. Error bar $=2 S E$. 
Plate II
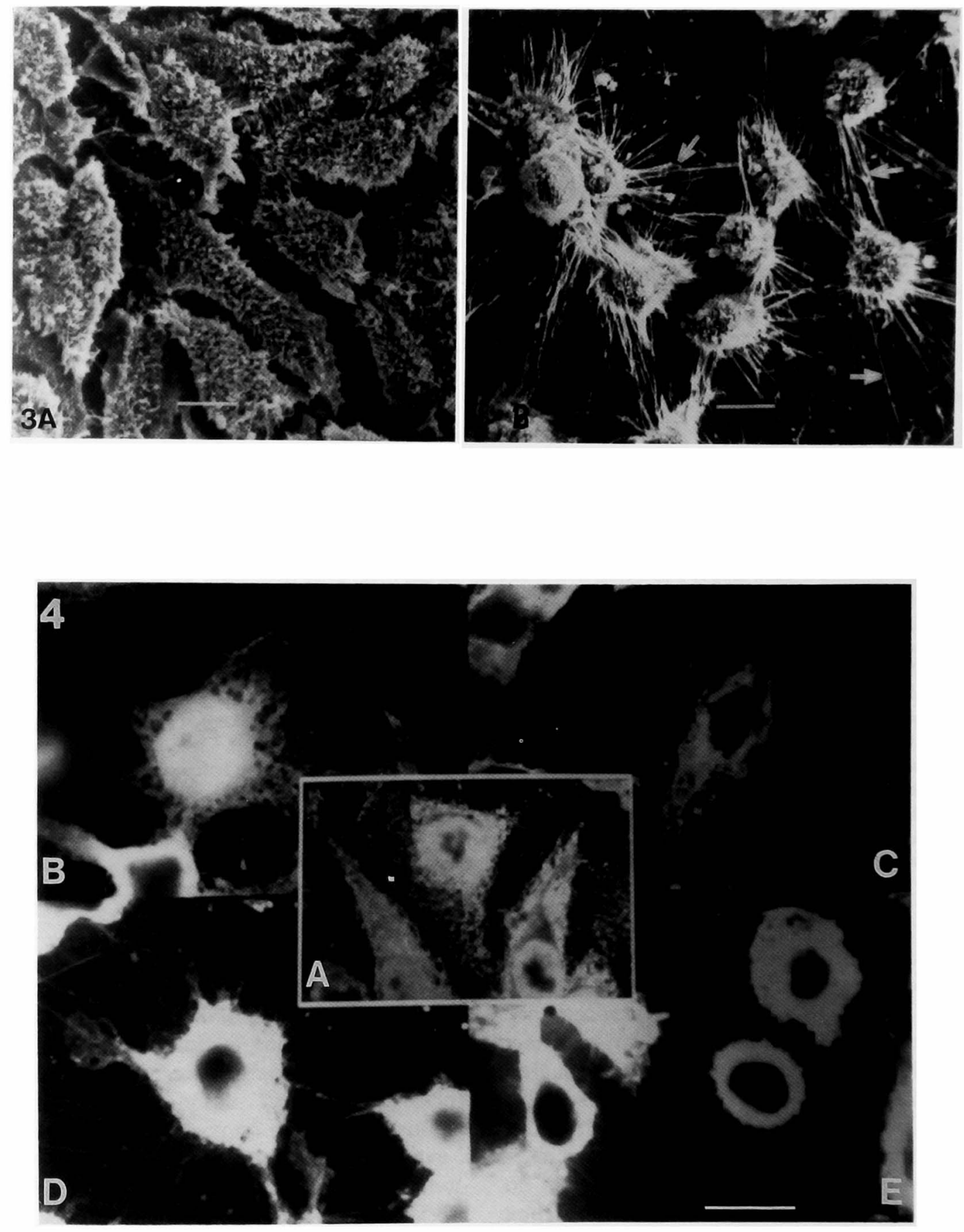

Plate II

Fig. 3. Scanning electron micrograph of Chang liver cells. (A) Untreated Chang cell. (B) ATP-treated Chang cell after 15 minutes. Bar $=10 \mu \mathrm{m}$.

Fig. 4. Confocal microscopic images of ATP-induced cell rounding: time response. (A) 0 minutes (B) 2 minutes (C) 4 minutes (D) 8 minutes (E) 15 minutes. Bar $=10 \mu \mathrm{m}$. 